\title{
Medical Infrastructure and Not Medical Insurance Should Be the Focal Point to Tackle Pandemic in Developing Countries Like India: A Study
}

\author{
Anuska Larokar ${ }^{1}$, Shantanu S. Bose ${ }^{2}$, Ravi Rathi ${ }^{3}$, Rakesh Kumar Jha ${ }^{4}$ and Karuna Kachawa ${ }^{5}$ \\ ${ }^{1}$ Student Datta Meghe Institute of Management Studies, Nagpur, India \\ ${ }^{2}$ Datta Meghe Institute of Management Studies, Nagpur, India \\ ${ }^{3}$ CEO Rathi Investments \\ ${ }^{4}$ Deprtment of Biochemistry Datta Meghe Medical College, Shalinitai \\ Meghe Hospital and Research Centre Nagpur. \\ ${ }^{5}$ Deprtment of Biochemistry Jawaharlal Nehru Medical College, Datta Meghe \\ Institute of Medical Sciences Sawangi (Meghe) Wardha \\ Corresponding author email: bose.shantanu@rediffmail.com
}

\section{ABSTRACT}

India is experiencing a brutal onslaught of second severe savage of corona wave and its ominous impact on lives and livelihood. A shaking health care system and a tottering economy are staring on our face. The citizen as well as the government is realizing that there is a vast scope of improvement in the medical infrastructure throughout the nation. The present heath care system proving to be inadequate to serve this vast population. The country is realizing the shortage of medical staff, frontline health workers and over and above a great paucity of proper medical infrastructure set up. This is an ominous sign. India needs more number of hospitals, trained doctors, nurses and other trained health care workers to meet several challenges in its heath care system. Considering these it is imperative to focus on set up of medical infrastructure instead of giving emphasis on medical insurance. For this government should formulate proper policies on set up of medical infrastructure and should spend more on public health care. In-fact the average spending by government on public health care for last five years is $1.28 \%$ of Gross Domestic product (GDP), which is even lesser than the average spending of OECD countries i.e 8\% of GDP. A study has been made to prove that medical infrastructure and not the medical insurance scheme like Ayushman Bharat Yojana is the need of the hour.

KEY WORDS: MEDICAL INFRASTRUCTURE, MEDICAL INSURANCE, GROSS DOMESTIC PRODUCT, GOVERNMENT EXPENDITURE, PUBLIC HEALTH CARE,

\section{INTRODUCTION}

As India faces a brutal onslaught of second severe savage of corona wave, its impact on lives and livelihood is

Biosc Biotech Res Comm P-ISSN: 0974-6455 E-ISSN: 2321-4007

\section{crossef}

Identifiers and Pagination

Year: 2021 Vol: 14 No (6) Special Issue

Pages: 271-274

DOI: $h t t p: / / d x$.doi.org/10.21786/bbrc/14.6.57
This is an open access article under Creative

Commons License Attribn 4.0 Intl (CC-BY). proving to be devastating.A shaking health care system and a tottering economy arestaring at our face. The citizen as well as the government is realizing that there is a vast scope of improvement in the medical infrastructure throughout the nation. The present heath care system proving to be inadequate to serve this vast population. The country is realizing a great dearth of hospitals, nursing homes, doctors, health workers and other medical facilities which are very much essential for a formidable heath care system. The economy survey of 2019-2020 has categorically pointed out the shortage of doctors in the country. The doctor population ratio in India is

\section{Article Information \\ Received: 27 March 2021}

ccepted after revision: $28^{\text {th }}$ May 2021 
1:1456 as against World Health Organization (WHO) recommendation OF 1:1000.

This simply shows the miserable condition of our health system. The health care system both in urban and rural areas are under tremendous stress. As per the District Hospital Booklet published by NITI Aayog, at present the total number of hospitals with bed count of 101-200 is 197, with 201-300 beds is 138 and 301 and above is 201 and others consist of 198. This simply shows the total number of district hospitals are only 734 to serve a population of over 140 crores. This is an ominous sign. India needs more number of hospitals, trained doctors, nurses and other trained health care workers to meet several challenges in its heath care system.

Although there has been some endeavor to set up adequate medical infrastructural facilities but it is proving meagre. On the other hand the Central government in its policies is trying to put emphasis on procurement of medical insurance policies like'Ayushman BharatYojna' which is not at all an alternative to boost up the medical system. 'Ayushman Bharat' is basically a insurance scheme, which is being procured to 50 crore people as per government declaration. But one thing should be kept in mind that for launching and running any medical insurance schemes actively for this vast population requires huge amount of expenditure. If we consider this Ayushman Bharat Scheme, it requires at least an investment of Rs.1.5 crore to Rs. 2 crores by way of payment of premium to the insurance company. Secondly these insurance policies are beneficial only if the person (who is covered by the insurance policy) fall sick. If that particular person doesn't then the entire amount of premium will go in vain.

Rather one can say that this medical insurance schemes benefits the insurance company rather than the people. This is in fact an US model. What India needs is the European model where in a country needs goods medical infrastructure to serve its citizen at the optimum level. This research paper has tried to show how the current medical infrastructural facilities are inadequate and the country needs a sound and resolute medical infrastructure facilities instead of medical insurance policies. It also focuses on how much spending has been done by the government over the past five years for developing a sound medical system for the country in terms of its GDP. It also focuses on how much is the contribution of insurance sector by way of medical insurance towards health and economic development of the nation.

Table 1. Government spending on healthcare from 2016-2017 to 2020-2021

\begin{tabular}{|l|c|c|c|}
\hline Year & $\begin{array}{c}\text { Spending on } \\
\text { Healthcare Rs. } \\
\text { in Crores }\end{array}$ & $\begin{array}{c}\text { Percentage } \\
\text { of GDP }\end{array}$ & $\begin{array}{c}\text { Increase in } \\
\text { percentage over } \\
\text { previous year }\end{array}$ \\
\hline $2020-2021$ (Revised Estimates) & 82,445 & 1.26 & 30.00 \\
\hline $2019-2020$ (Actuals) & 63,425 & 1.60 & 16.00 \\
\hline $2018-2019$ (Actuals) & 54,477 & 1.28 & 02.80 \\
\hline $2017-2018$ (Actuals) & 52,994 & 1.28 & 36.00 \\
\hline $2016-2017$ (Actuals) & 39,005 & 1.02 & 14.28 \\
\hline
\end{tabular}

(Source: Expenditure statements of Union Budget.www.indiabudget.gov.in)

Government spending on medical infrastructure and health care: If we look at the budget of 2021-2022, the estimated expenditure in health care rose from $1.2 \%$ to 2.5\%of Gross Domestic Product (GDP). But the question is that is it enough for the development of overall medical infrastructure in the country. The following data tries to make a comparison between the government pending on heath (that includes medical infrastructure) and development of medical infrastructure over the past five years.

From the table No1, it can be interpreted that the government spending on health care as percentage of GDP is very precarious. In fact it can be considered as no spending at all. If we look at the spending as percentage of GDP it si 1.02 in 2016-2017, 1.28 in 20172018, again same in the year 2018-2019 having a mere increase in $0.32 \%$ in 2019-202 over the previous year and now by way of revised estimates it is 1.26 in 2020-
2021. In fact when the actual figures will be published it will even be lower in 2020-2021. This indicate quite intimidating situation. Because of this we can see a huge gap of demand and supply in the medical infrastructural facility in the country, epically in this horrific pandemic situation.

Again if we look at the increase in spending over the previous we can get an uneven increase. In fact in no years the increase in percentage of spending over the previous year crosses more than 50\%. By plotting these figures in graph we can get an almost steady flat line with respect to $\mathrm{X}$ axis. It simply shows that the government expenditure on health care as percentage of GDP is very parsimonious. On the other hand the increase in percentage of spending over previous year is quite erratic. After shape rise in financial year of 2017-2018, one can noticed noose dived in year 2018-2019. After that it is showing a steady increase in from 2019-2020 and in 
2020-2021 as per the revised estimates. These shows us quite discouraging for sound development of heath care system and medical infrastructure in the country.

Comparison of health care investment in developed countries and that of India: A per the report of Organization for Economic Cooperation and Development (OECD) India's total healthcare spending (that constitutes out-of-pocket and public) is 3.6\% of GDP, which is far lower than other OECD countries The repot tells us thatthe average spending on the health care system by these countries is for OECD countries in 2018 was 8.8\% of GDP. Among the developed countries United State of America spends almost 17\%, Germany $11.2 \%$, France $11.2 \%$ and Japan $10.9 \%$ of their total GDP respectively. This completely shows that India stand far below in the index as far as the spending on health and medical infrastructure is concerned. If this continue, then it will become very difficult to procure a resolute health services to this vast population. This we are experiencing at present when are facing the brutal onslaught of second wave of Covid-19.

Consequences of inadequate spending on health care:As we have seen that the government spending on health care service in India is quite inadequate and hence facing several consequence like inadequate and appropriate medical infrastructure to serve this vast population of 140 crore people. The second wave of Covid-19 has shown that for serving only $10 \%$ of total population our system has become overwhelmed. There is great dearth of each and every medical requirement to serve this vast population. Right from the lack of doctors and other frontline medical worker to adequate number of hospitals ad from medical equipment to oxygen supply we are noticing a precarious situation.

Graph 1: Showing Government spending on healthcare as percentage of GDP and increase in percentage over previous year

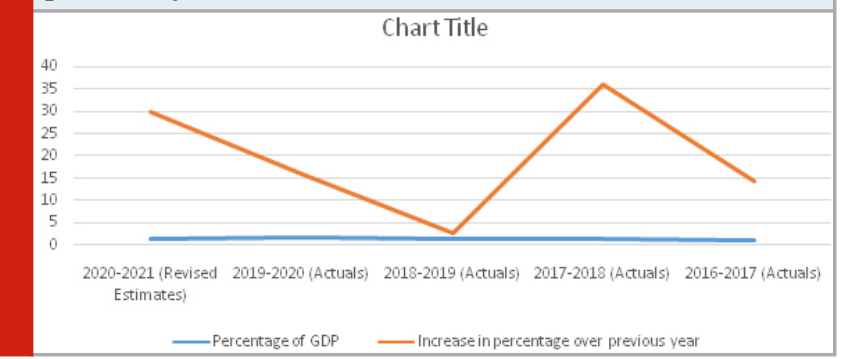

The procumbent of basic medical facilities to the residents of this country is at stake due to lack of government spending in the public health care system. We are facing great dearth of doctors to serve this huge population and this is clear by the doctor population ratio of $1: 1456$ as against World Health Organization (WHO) recommendation Of 1:1000. Along with that there is also paucity of supporting health care staff like nurses, ward boys in hospitals, paramedical staff and other frontline heath care workers to attend this vast population. Although it is perceiving that private sector is coming up and will make a great contribution in setting up of a formidable heath care system in India, but it has been noticed that in the health care service if the public sector failed to up hold the system the private sector is no better than the public sector.

It has been observed that profit motive is the prime objective of the private sector. The private sector always aims at the recovery of capital investments made by them and also to surpass the operating cost that are being incurred for rendering the services. That's why the public investment is very much essential to incur a heavy basic expenditure on the health care system by both the state and central government. If at all the central as well the state governments are finding it difficult to incur a heavy expenditure on medical infrastructure , then the government can think over the public private partnership to mitigate this challenge. Unless and until the public spending on health care is increased it is quite difficult to have a formidable medical infrastructure in the vast country.

Comparison of medical insurance with that of medicalinfrastructure facility: In the recent years the Government of India is focusing more on medical insurance policy rather than the medical infrastructural facility. Aysuhman Bharat Yojana is prime example of this issue. Now the question is why spending on medical infrastructure is more important than spending on medical insurance? The answer is very practical one. For example, when the government spends by way of premium for medical insurance policies it can benefit the only the people when they fall sick otherwise as we know that premium of medical insurance will go in vain if that person doesn't fall sick. In other words medical insurance doesn't give any guarantee that it will really benefit the people. In fact through the various assessment over the years it has been observed that the medical insurance is beneficial more to the insurance companies rather than the people.

Secondly medical insurance can be beneficial only in those countries which have sound and resolute medical infrastructure. This can be experienced during the onslaught of second wave of Covid -19 in India. Despite having medical insurance or insurance under Ayushman Bharat Yojana many people are finding it difficult to get a proper treatment in this Covid-19 situation due to lack of medical infrastructure. In many cases we have seen that people in serious conditions are not getting a bed in the hospitals.

There is great dearth of oxygen supply for the patients who are in ominous condition. Even at time we can see those heart wrenching seen where the people are begging for oxygen and a bed in the hospital to ameliorate the precarious situation of their near and dear ones. At times serious patient are compelled to inhale oxygen by sitting in their car or by laying outside the hospitals or in the coli door of the hospital etc. This things would have never happened, had there been proper arrangements of beds, oxygen and other medical facilities. This can 
be done only when proper infrastructural development can be set up which requires a sumptuous government spending towards the healthcare system. (Butola et al. 2020) This simply suggests that medical insurance is of no use if the nation lacks appropriate and adequate medical infrastructure facility.

Again another dimension can be viewed that even in case of health insurance the companies are also incurring losses with respect to net premium earned and claim settlement. Many a times it is happening that even these insurance companies are finding it difficult to run the business. (Dhok et al. 2020) As per one research paper by Madan Mohan Dutta in Emerald September 2020, it has been mentioned that with the growth of premium in the health insurance sector in the recent years the claims, commission and administrative expenses has also grown substantially, and even at times the amount of these claim settlements, and other operational expense surpass the net premium earned by the insurance companies.

This results into incurring of losses not only by the insurance sector but for the nation's economic development. Therefore it is very much essential by these general insurance companies to pay necessary attention to control their operating cost8. Even the recent data in the hand book of Indian Insurance Statistics published by Insurance Regulatory Development Authority (IRDA) shows that the insurance companies are also incurring losses because of its high operational cost. Therefore it would be wise to for the government to frame a proper policies on the development of medical infrastructure instead of giving primary focus to health insurance scheme like Ayushman Bharat Yojana.

\section{CONCLUSIONS \& SUGGESTIONS}

On the basis of the above study it can be concluded that the spending on health sector by the government is quite inadequate and as percentage of GDP it is very low as compared to developed countries. Even it can be observed that for the last five years the average spending on the health sector is only $1.28 \%$ of total GDP of the nation. Again if we look at the increase in the year wise spending the trend is very much erratic. At times in some specific years the government spending has gone up stiffly over the previous year. For example from the table 1 and graph 1 it can be concluded that the government sending has gone up by $21.72 \%$ again it has gone down in the next year i.e. in the year 2018-2019 by 33.2\%. This shows a complete erratic government spending on public health care.

Another thing to be noted is that as per OECD report the average spending by the OECD countries is $8.8 \%$ which of their GDP which is very much higher than Indian spending on the health care system. Secondly the focus on medical insurance schemes like Ayushman Bharat Yojana is not very lucrative one. It can be concluded that instead of benefiting the people it benefits the insurance companies. But again saying that one can see even the insurance companies are also incurring the losses in case of health insurance because of its high operating costs.

In order to improve the medical infrastructure in the country spending on public health care is more lucrative instead of spending on health insurance scheme by way of premium. Therefore it is suggested that the prime focus of the government should be to improve the health infrastructure. For that the proper policy should be formulated both at the state and central level to rejuvenate the entire heath infrastructure of the country. Every year the both the central and various state government should made provision in their budget for improvement in the health infrastructure scheme. The government should improve its spending on health care with respect to GDP. At least it must match the average spending of the OECD countries. If this has been done in an appropriate manner, India can have a formidable health care system and tackle this pandemic situation like Covid-19 in resolute manner.

\section{REFERENCES}

Arora, D., Sharma, M., Acharya, S., Shukla, S. and Acharya, N., 2020. India in "Flattening the Curve" of COVID-19 Pandemic-Triumphs and Challenges Thereof. Journal of Evolution of Medical and Dental Sciences, 9(43), pp.3252-3256.

Butola, L.K., Ambad, R., Kute, P.K., Jha, R.K., Shinde, A.D. and DMIMS, W., 2020. The Pandemic of 21st Century-COVID-19. Journal of Evolution of Medical and Dental Sciences, 9(39), pp.2913-2919.

Dhok, A., Butola, L.K., Anjankar, A., Shinde, A.D.R., Kute, P.K. and Jha, R.K., 2020. Role of Vitamins and Minerals in Improving Immunity during Covid-19 Pandemic--A Review. Journal of Evolution of Medical and Dental Sciences, 9(32), pp.2296-2301.

Dutta, M.M., 2020. Health insurance sector in India: an analysis of its performance. Vilakshan-XIMB Journal of Management.

Latchoumi, T.P., Ezhilarasi, T.P. and Balamurugan, K., 2019. Bio-inspired weighed quantum particle swarm optimization and smooth support vector machine ensembles for identification of abnormalities in medical data. SN Applied Sciences, 1(10), pp.1-10.

Long, T.D., 2016. Executive Compensation, Firm Performance, and Net Community Benefits Within Nonprofit Urban Hospitals.

Nor, N.A.U.M., Solehan, H.M., Mohamed, N.A., Hasan, Z.I.A., Umar, N.S., Sanip, S. and Rani, M.D.M., 2020. Knowledge, attitude and practice (KAP) towards COVID19 prevention among Malaysian adults during the period of Movement Control Order (MCO): An online cross-sectional survey. International Journal of Research in Pharmaceutical Sciences, pp.1458-1468.

Salesman, F., Tapung, M.M. and Setiawan, L.I., 2018. Strategy And Policy Increasing Human Development Index Of Manggarai Regency 2016-2021. Sinergi: Jurnal Ilmiah Ilmu Manajemen, 8(1).

Verma, A. and Bala, R., 2013. The relationship between life insurance and economic growth: Evidence from India. Global Journal of Management and Business Studies, 3(4), pp.413-422. 